\title{
The effect of work level and dietary intake on water balance and the excretion of sodium, potassium and iron in a hot climate
}

\author{
BY ERICA F. WHEELER \\ Department of Human Nutrition, London School of Hygiene and Tropical Medicine, \\ Keppel Street, London WCI ${ }_{7} H T$ \\ AND HAMAD EL-NEIL \\ Department of Physiology, Faculty of Medicine, \\ University of Dar es Salaam, Tanzania \\ AND J. O. C. WILLSON AND J. S. WEINER \\ MRC Environmental Physiology Unit, London School of Hygiene and \\ Tropical Medicine, Keppel Street, London WCx $E_{7} H T$ \\ (Received 31 August 1972-Accepted I8 Fanuary 1973)
}

\begin{abstract}
r. The dietary intake, and urinary, cutaneous and faecal loss of water, sodium, potassium and iron have been studied in young men living and performing moderate work in a hot climate. The dietary intakes of $\mathrm{K}$ and $\mathrm{Fe}$ were lowered during part of the study.

2. The subjects were already somewhat acclimatized to heat; further acclimatization was achieved when they were performing work, and this was assessed in terms of the increase in their rate of sweating.

3. The subjects tended to be in marginally negative $\mathrm{Na}$ balance, partly owing to lowered $\mathrm{Na}$ intakes. Intakes and outputs of $\mathbf{K}$ were in balance. Losses of $\mathrm{K}$ in sweat amounted to $15 \%$ of intake when the dietary level was reduced.

4. The subjects were slow in adapting to changes in Fe intake, $8 \mathrm{~d}$ being an insufficient period for adaptation after their intake had been halved. Losses of $\mathrm{Fe}$ in sweat were approximately $0.3 \mathrm{mg} / \mathrm{d}$, or one-third of the estimated requirement for absorbed $\mathrm{Fe}$.

5. It is concluded that Fe losses in sweat could be a significant factor in Fe depletion if dietary $\mathrm{Fe}$ was low or unavailable, as there was no evidence that a low intake and absorption affected sweat losses.
\end{abstract}

In an earlier paper (Weiner, Willson, El-Neil \& Wheeler, I972) we reported an investigation into the effect of a low-nitrogen diet and a moderate work-load on the $\mathrm{N}$ excretion of young men who had spent all their lives in a hot climate. In particular, we considered $\mathrm{N}$ losses in sweat, as these are especially relevant to the nutritional status of workers in tropical climates. We found that $\mathrm{N}$ losses by sweating were small, decreasing when the dietary $\mathrm{N}$ intake was low. The faecal and urinary losses accounted for over $90 \%$ of the output both on high and low $\mathrm{N}$ intakes.

In addition to $\mathrm{N}$, assessments were also made of water, sodium, potassium and iron balances, again with particular reference to the contribution made by sweating to the daily losses of these constituents. All of these constituents are relevant to the nutritional adjustments and stresses peculiar to hot climates. Maintenance of an adequate $\mathrm{Na}$ and water balance is essential for workers performing physical activity in hot conditions. In view of the prevalence of anaemia and the frequency of low Fe intake in the tropics, skin loss could have an important effect on Fe status. European studies 
Table I. Age, mean body-weight, and height of the six Tanzanian male adults

$\begin{array}{cccc}\text { Subject } & \begin{array}{c}\text { Age } \\ \text { (years) }\end{array} & \begin{array}{c}\text { Body-wt* } \\ \text { (kg) }\end{array} & \begin{array}{c}\text { Height } \\ \text { (m) }\end{array} \\ \text { FK } & 26 & 68 \cdot 24 & \\ \text { CM } & 25 & 67 \cdot 53 & \mathrm{I} \cdot 745 \\ \text { JS } & 23 & 53 \cdot 14 & \mathrm{I} \cdot 800 \\ \text { FM } & 24 & 63 \cdot 24 & 1 \cdot 670 \\ \text { GU } & 24 & 53 \cdot 01 & \mathrm{I} \cdot 630 \\ \text { EM } & 24 & 57 \cdot 85 & 1 \cdot 770\end{array}$

* Mean values: subjects weighed immediately on waking.

(Bothwell, 1970) suggest that more Fe is lost from skin than from urine and that skin losses could account for as much as one-third of the total absorbed Fe. Loss of $\mathrm{K}$ in sweat is of some interest in view of the finding of severe muscle $\mathrm{K}$ depletion in protein-energy malnutrition (Waterlow, Cravioto \& Stephen, 1960). Information on the $\mathrm{Fe}$ and $\mathrm{K}$ balances of normal tropical subjects (either children or adults) is meagre.

This investigation was carried out on young adults who were following an ordinary routine of moderate work and consuming their customary foods. The changes made in their routine for the purpose of this investigation were $(a)$ to increase their activity and sweat output in one experimental period, $(b)$ to decrease the $\mathrm{N}$ intake in a further experimental period. Salt intakes were kept at constant levels chosen by the subjects, and water was freely available. It was found that on the low- $N$ diet there was an associated reduction in both $\mathrm{K}$ and $\mathrm{Fe}$ intake, so for these nutrients we were also able to study the effects of a reduced intake on losses, particularly in the sweat.

\section{EXPERIMENTAL}

The following is a brief account of our experiment, which has been described more fully in a previous paper (Weiner et al. 1972).

The volunteer subjects were six male Tanzanian medical students, and the study was carried out in Dar es Salaam, Tanzania, during April, May and June I969. Details of age, weight and height are given in Table $\mathbf{I}$.

The three experimental periods ('Table 2) each consisted of a 'run-up' period ( $3 \mathrm{~d}$ in studies 1 and $2,5 \mathrm{~d}$ in study 3 ), during which equilibration on a constant diet was established, followed by the study period of $3 \mathrm{~d}$. During the study period the diet was strictly controlled, excreta were collected, and careful note was kept by personal diaries of the subjects' activity throughout the $24 \mathrm{~h}$.

In studies 2 and 3 , the work consisted of rhythmic stepping using a step $230 \mathrm{~mm}$ high, at environmental temperatures (average $32^{\circ}$ dry-bulb, $28^{\circ}$ wet-bulb) similar to the outside shade temperatures. Apart from this work, the subjects had a set routine of reporting to the laboratory, where they carried out a number of simple tasks such as recording environmental temperatures and acting as clerks in connexion with tests going on.

During each study period the ingredients and quantity of the subject's diet were 
Table 2. Work level, range of dietary intake, and water loss from skin of the six Tanzanian male adults in the three study periods

\begin{tabular}{|c|c|c|c|c|c|c|c|}
\hline \multirow[b]{2}{*}{$\begin{array}{l}\text { Study } \\
\text { period }\end{array}$} & \multirow[b]{2}{*}{ Work level } & \multicolumn{5}{|c|}{ Range of dietary intake* } & \multirow{2}{*}{$\begin{array}{c}\text { Skin } \\
\text { water } \\
\text { loss } \\
(1 / 3 d)\end{array}$} \\
\hline & & $\begin{array}{c}N \\
(g / d)\end{array}$ & $\underset{\text { (mequiv./d) }}{\mathrm{Na}}$ & $\underset{\text { (mequiv./d) }}{\mathrm{K}}$ & $\underset{(\mathrm{mg} / \mathrm{d})}{\mathrm{Fe}}$ & $\begin{array}{l}\text { Water } \\
(1 / 3 d)\end{array}$ & \\
\hline $\mathbf{I}$ & $\begin{array}{r}\text { Habitual activity } \\
\text { (high } N \text { intake) }\end{array}$ & $10-13$ & $150-200$ & $65-90$ & $28-45$ & $10 \cdot I-12 \cdot 2$ & $3 \cdot 9-7 \cdot 6$ \\
\hline 2 & $\begin{array}{l}\text { Habitual activity } \\
\text { and } 2 \mathrm{~h} \text { work/d } \\
\text { (high } \mathrm{N} \text { intake) }\end{array}$ & $10-13$ & $150-200$ & $65-90$ & $28-45$ & $10 \cdot 6-15 \cdot 2$ & $5 \cdot 1-I I \cdot 3$ \\
\hline 3 & As 2 (low $N$ intake) & $4-6$ & $150-200$ & $55-75$ & $15-24$ & II $\cdot 0-14 \cdot 1$ & $5 \cdot 9-7 \cdot 6$ \\
\hline
\end{tabular}

kept constant. Food was cooked in distilled water, without salt, in aluminium utensils. Each subject was given a weighed allowance of salt for the day. The amount of this allowance was chosen by the subject and adjusted to his taste during the run-up period. Distilled water for drinking was freely available, and the subjects measured their own water intakes. The diets were based on the menu of the medical students' hostel, where they were prepared, but in studies I and 2, relatively generous quantities of meat, milk and fruit were provided. In study 3 all protein-rich foods were excluded in order to provide a low- $\mathrm{N}$ diet, and this brought about reduced intakes of $\mathrm{Fe}$ and $\mathrm{K}$ also. A moderate amount of alcohol was included in the diets (approximately ro $\mathrm{g}$ alcohol/man per $\mathrm{d}$ ).

The subjects were weighed daily in the nude, on a Spido man-balance, immediately on waking and again before retiring at night. Urine and faeces were collected during the study periods, and whole-body sweat was also collected by washing the subjects twice daily in distilled water and rinsing their clothes and towels. A sample of the washings was taken for analysis. The volume of sweat (CW (ml)) produced daily was calculated as follows:

$$
\mathrm{CW}=\mathrm{F}+\mathrm{D}-(\mathrm{U}+\mathrm{S}+\Delta \mathrm{w})-300-\mathrm{C},
$$

where $\mathrm{CW}=$ cutaneous water loss $(\mathrm{ml}), \mathrm{F}=$ weight of food intake $(\mathrm{g}), \mathrm{D}=$ volume of fluid intake $(\mathrm{ml}), \mathrm{U}=$ volume of urine produced $(\mathrm{ml}), \mathrm{S}=$ weight of faeces produced $(\mathrm{g}), \Delta \mathrm{w}=$ change in body-weight $(\mathrm{g}), 300=$ arbitrary value for respiratory loss $(\mathrm{ml})$, and $\mathrm{C}=\mathrm{CO}_{2}$ output $-\mathrm{O}_{2}$ intake $(\mathrm{g})$. Water balance $(\mathrm{ml})$ was calculated from input and output as follows:

$$
\mathrm{W}=\mathrm{FW}+\mathrm{D}+\mathrm{A}+\mathrm{M}-(\mathrm{U}+\mathrm{SW}+\mathrm{CRW}),
$$

where $\mathrm{W}=$ positive or negative water balance $(\mathrm{ml}), \mathrm{FW}=$ water content of food (by analysis) ( $\mathrm{ml}), \mathrm{D}=$ volume of fluid intake $(\mathrm{ml}), \mathrm{A}=$ water from the metabolism of alcohol $(\mathrm{ml}), \mathrm{M}=$ metabolic water produced $(\mathrm{ml}), \mathrm{U}=$ volume of urine produced $(\mathrm{ml}), \mathrm{SW}=$ water content of faeces $(\mathrm{ml})$, and $\mathrm{CRW}=$ cutaneous and respiratory water loss $(\mathrm{CW}+300)(\mathrm{ml})$. The alcohol content of the subjects' drinks was calculated from the food composition tables of McCance \& Widdowson (I960). Metabolic water 
production $(\mathrm{M})$ is generally calculated from dietary protein $(\mathrm{P})$, fat $(\mathrm{F})$ and carbohydrate $(\mathrm{C})$ as follows:

$$
\mathrm{M}=0.4 \mathrm{I} \mathrm{P}+\mathrm{I} \cdot 08 \mathrm{~F}+0 .{ }_{55} \mathrm{C} .
$$

We assumed that, in studies $I$ and 2 , the proportions of these nutrients were $P: F: C=I: I: 5$, these being the proportions found in normal diets. For the low- $N$ diet in study 3, we took the proportions as $\mathrm{P}: \mathrm{F}: \mathrm{C}=0.25: \mathrm{I}: 5$. The correctness of these assumptions was confirmed by chemical determination of the $\mathrm{N}$ and energy contents of the diets (Weiner et al. 1972).

A final correction was made in the calculation for the difference in weight between $\mathrm{O}_{2}$ intake and $\mathrm{CO}_{2}$ output, which was taken to be I $_{5} \mathrm{~g} / \mathrm{d}$.

During the run-up periods, whole-body sweat was also collected under conditions of controlled hyperthermia by means of the hyperthermia test bed (Fox, 1967). Sweat output estimated by both of these methods was used to assess the subjects' degree of acclimatization to heat.

\section{Analytical methods}

All food and faeces were homogenized, sampled and dried before analysis. Wholebody sweat was filtered; thus calculations of the nutrient content of sweat do not include cell debris.

$\mathrm{Na}$ and $\mathrm{K}$ were determined in urine and sweat by means of an EEL Clinical flame photometer (Evans Electroselenium Limited, Halstead, Essex). Dried food and faeces were ashed at $45^{\circ}$ in a muffle furnace, and the ash was taken up in dilute $\mathrm{HCl}$. The $\mathrm{Na}$ and $\mathrm{K}$ contents of this solution were then measured with the flame photometer.

The Fe determinations presented greater technical problems because of the risk of contamination. Most of the work was done in a room which had been washed down beforehand; reagents for the urine and sweat analyses were rendered Fe-free before use; all glassware was washed in dilute $\mathrm{HCl}$ and glass-distilled water, and metallic equipment was covered with aluminium foil. The Fe content of urine and sweat was determined as described by Man \& Wadsworth (1969), who modified the method of Bothwell \& Mallett (1955). This method involves the formation of a coloured complex between ferrous iron and bathophenanthroline. Food and faeces were analysed by the method of Wootton (1958) as modified by Hegarty (1966). The material was digested with concentrated nitric acid, and the colour was developed by the addition of perchloric acid.

\section{RESULTS}

\section{Water balance}

Table 3 shows the subjects' water intake and output. In studies 2 and 3 , in response to the extra work in a very warm room, our subjects drank more fluid (analysis of variance gives $P<0.002$ ) and produced more sweat (as cutaneous loss) than in study I. Paired $t$ tests showed that the sweat rates during the controlled hyperthermia tests were also significantly increased in studies 2 and 3 , indicating that the subjects had undergone some degree of acclimatization to the additional heat load (Weiner et al. 1972). The faecal losses of water remained, on average, similar throughout. In 
Table 3. Water intake and output of six Tanzanian male adults for each study period

\begin{tabular}{|c|c|c|c|c|c|c|c|}
\hline & & & & tal for $3 \mathrm{~d}(\mathrm{n}$ & & & \\
\hline & & & & Output & & & \\
\hline $\begin{array}{l}\text { Study } \\
\text { period }\end{array}$ & Subject & Intake* & Urine & $\begin{array}{c}\text { Cutancous } \\
\text { and } \\
\text { respiratory }\end{array}$ & $\begin{array}{l}\text { Faecal } \\
\text { water }\end{array}$ & Balance & $\begin{array}{c}\text { Balance } \\
(\mathrm{ml} / \mathrm{d})\end{array}$ \\
\hline I & JS & 10109 & 3405 & 6722 & $44^{8}$ & -466 & $-I 55$ \\
\hline & FK & 10706 & 6195 & 3921 & 1077 & -487 & -162 \\
\hline & CMI & 12211 & 4305 & 7608 & $3^{6 I}$ & -63 & $-2 I$ \\
\hline & EM & I I 202 & 5405 & 5323 & 335 & +139 & +46 \\
\hline & GU & 10984 & 5525 & $43^{65}$ & 606 & +488 & $+16_{3}$ \\
\hline & FM & I I 650 & 6257 & 4890 & 268 & +235 & +78 \\
\hline & Mean & I I I44 & $5+82$ & 5472 & $5^{16}$ & -26 & -8 \\
\hline 2 & $\mathrm{JS}$ & I I 880 & 2610 & 9512 & 392 & -634 & $-21 I$ \\
\hline & FK & I 348 I & 4395 & 8526 & 386 & +174 & +58 \\
\hline & CM & I 5231 & 3350 & I I 284 & 229 & +368 & +123 \\
\hline & EM & 11122 & 4105 & 6863 & 347 & -193 & -64 \\
\hline & GU & 10615 & 4880 & 5063 & 585 & +87 & +29 \\
\hline & FM & × 1217 & 4770 & $6 I 10$ & 524 & -187 & -62 \\
\hline & Mean & 12258 & 4018 & 7893 & 410 & -64 & $-2 \mathrm{I}$ \\
\hline 3 & JS & 12387 & 5390 & 7024 & 448 & -475 & -158 \\
\hline & FK & 13711 & 7490 & $632 \pi$ & $75^{I}$ & $-85 I$ & -284 \\
\hline & $\mathrm{CM}$ & 14055 & $6 I 85$ & 7632 & $44^{\circ}$ & -202 & -67 \\
\hline & EM & I I 058 & 3355 & $75^{67}$ & 484 & -348 & - I 16 \\
\hline & GU & I I 850 & 5035 & 5937 & 572 & +306 & +102 \\
\hline & FM & I 2 I 59 & 5 II 5 & 7477 & 333 & -766 & -255 \\
\hline & Mean & 12537 & 5428 & 699.3 & 505 & $-3^{89}$ & -130 \\
\hline
\end{tabular}

study 2 the cutaneous loss was greater than in study $\mathrm{I}$ and there was a reduced urine output. In study 3 the cutaneous loss was greater than in study I, but was not accompanied by a reduction in urine output.

In all the studies the maximum individual negative water balance, over a $3 \mathrm{~d}$ period, was $6 \%$ of intake; the mean balances for the whole group were $-0.2 \%,-0.5 \%$ and $-3.1 \%$ of intake in studies $\mathrm{I}-3$ respectively. The results thus show that during the first two $3 \mathrm{~d}$ periods the subjects were regulating their water balance quite efficiently, but to a lesser extent during the third period. When intakes of individual days were considered, we find that on thirty out of fifty-four occasions our subjects were in some degree in negative water balance, but the extremes of the range of positive and negative were +574 and $-710 \mathrm{ml} / \mathrm{d}$, thus not exceeding $\mathrm{r} \cdot 3 \%$ of total body-weight.

\section{Na and $K$ balance}

Tables 4 and 5 show the subjects' intakes and outputs of $\mathrm{Na}$ and $\mathrm{K}$ during the three study periods. Wilson, Olney, Brooks, Myrden, Ball \& Moore (1954) showed that the average reproducibility of isotopic studies of $\mathrm{Na}$ turnover was $4 \%$; under the conditions of these experiments, and taking the error of collection and analysis into account, we do not consider a calculated 'balance' for $\mathrm{Na}$ or $\mathrm{K}$ to be significant unless 
Table 4. Sodium intake, excretion and balance of six Tanzanian male adults for each study period

\begin{tabular}{|c|c|c|c|c|c|c|c|}
\hline \multirow{3}{*}{$\begin{array}{l}\text { Study } \\
\text { period }\end{array}$} & \multirow[b]{3}{*}{ Subject. } & \multicolumn{5}{|c|}{ Total for $3 \mathrm{~d}$ (mequiv.) } & \multirow{3}{*}{$\begin{array}{c}\text { Balance } \\
\text { (mequiv./d) }\end{array}$} \\
\hline & & \multirow[b]{2}{*}{ Intake } & \multicolumn{3}{|c|}{ Output } & \multirow[b]{2}{*}{ Balance } & \\
\hline & & & Urine & Sweat & Faeces & & \\
\hline \multirow[t]{8}{*}{$\mathrm{I}$} & JS & $45^{6}$ & $52 \mathrm{I}$ & 35 & 17 & -117 & -39 \\
\hline & FK & 523 & 718 & 19 & 44 & -258 & -86 \\
\hline & $\mathrm{CM}$ & 420 & $38 r$ & 29 & 27 & -17 & -6 \\
\hline & EM & 590 & 520 & 33 & 29 & +8 & +3 \\
\hline & $\mathrm{GU}$ & $59 \mathrm{I}$ & 504 & 35 & $2 \mathrm{I}$ & $+3^{T}$ & t Io \\
\hline & $\mathrm{FM}$ & 532 & 552 & 25 & 20 & -65 & -22 \\
\hline & Mean & $5+9$ & 533 & 29 & 26 & -70 & -23 \\
\hline & Mean/d & 173 & 178 & Io & 9 & - & - \\
\hline \multirow[t]{8}{*}{2} & JS & $65 \mathrm{I}$ & 599 & $7 \mathrm{I}$ & 12 & $-3 I$ & - I0 \\
\hline & $\mathrm{FK}$ & 564 & $5 \times 5$ & 45 & $3 \mathrm{I}$ & -18 & -6 \\
\hline & $\mathrm{CM}$ & 469 & 442 & 62 & 12 & -37 & -12 \\
\hline & EM & 488 & $49 \mathrm{I}$ & 77 & 27 & -107 & -36 \\
\hline & GU & 532 & 515 & 74 & 12 & -69 & -23 \\
\hline & FM & 504 & 485 & 53 & 18 & -53 & -18 \\
\hline & Mean & 535 & 506 & 64 & I9 & -53 & -18 \\
\hline & Mean/d & 178 & 169 & 21 & 6 & - & - \\
\hline \multirow{8}{*}{3} & JS & $69 \mathrm{I}$ & 639 & 56 & 56 & -60 & -20 \\
\hline & FK & 502 & $53^{8}$ & 43 & 59 & -138 & -46 \\
\hline & $\mathrm{CMF}$ & 462 & 432 & 82 & 53 & -105 & -35 \\
\hline & $\mathrm{EM}$ & 538 & 474 & 89 & 32 & -57 & -19 \\
\hline & GU & 525 & 400 & 75 & 45 & +5 & +2 \\
\hline & FM & 488 & 447 & $7 \mathrm{I}$ & 14 & -44 & $-x 5$ \\
\hline & Mean & 534 & 488 & 69 & 43 & -67 & -22 \\
\hline & Mean/d & 178 & 163 & 23 & $\pi_{4}$ & - & - \\
\hline
\end{tabular}

it exceeds $\pm 5 \%$ of intake. On this basis, subjects GU and FM were in Na balance throughout. Subjects JS, CM and EM were each in negative balance during one of the three studies, to the extent of $\mathrm{I} I-\mathrm{I} 2 \%$ of intake. The sixth subject, FK, was in marked negative balance in studies $I$ and 2 , and his urine excretion in study $I$ was surprisingly high.

For the group as a whole, the average $\mathrm{Na}$ intake remained fairly constant for each of the three studies ( $173^{-1} 7^{8}$ mequiv./d) despite the change in diet in study 3 . Of the excreta, the urine loss accounted for 89,85 and $8 \mathrm{r} \%$ of total loss in studies $\mathrm{I}-3$ respectively. Urine losses were also very close to intake, and our subjects' sweat $\mathrm{Na}$ loss was low compared with that found by Collins, Eddy, Hibbs, Stock \& Wheeler (I97I) or by McCance, El-Neil, El-Din, Widdowson, Southgate, Passmore, Shirling \& Wilkinson (I97I). The sweat loss, though small (about $6 \%$ of intake), doubled in studies 2 and 3 compared with study $\mathbf{I}$. This increase, which was accompanied by a reduction in urine $\mathrm{Na}$ loss, represents the outcome of an increase both of sweat $\mathrm{Na}$ concentration (see Table 7 ) and sweat $\mathrm{Na}$ loss (Table 3 ). The high sweat Na concentrations in studies 2 and 3 may possibly reflect the result of a higher skin temperature during the exercise period (Weiner \& van Heyningen, 1952). The fact that the sub- 
'Table 5. Potassium intake, output and balance of six Tanzanian male adults for each study period

\begin{tabular}{|c|c|c|c|c|c|c|c|}
\hline \multirow[b]{3}{*}{$\begin{array}{l}\text { Study } \\
\text { period }\end{array}$} & \multirow[b]{3}{*}{ Subject } & \multicolumn{5}{|c|}{ Total for $3 \mathrm{~d}$ (mequiv.) } & \multirow[b]{3}{*}{$\begin{array}{c}\text { Balance } \\
\text { (mequiv./d) }\end{array}$} \\
\hline & & \multirow[b]{2}{*}{ Intake } & \multicolumn{3}{|c|}{ Output } & \multirow[b]{2}{*}{ Balance } & \\
\hline & & & Urine & Sweat & Faeces & & \\
\hline \multirow[t]{8}{*}{$\mathbf{I}$} & JS & 225 & 137 & 34 & 53 & $+\mathrm{I}$ & +0.3 \\
\hline & FK & 196 & I 43 & 28 & 52 & -24 & $-8 \cdot 0$ \\
\hline & $\mathrm{CM}$ & 208 & III & 38 & 46 & +13 & +43 \\
\hline & EM & 273 & I96 & I 9 & 67 & -9 & $-3 \cdot 0$ \\
\hline & GU & 245 & 171 & I7 & 54 & +3 & $+I \cdot 0$ \\
\hline & FM & 225 & 153 & 18 & 24 & +30 & +10 \\
\hline & Mean & 229 & 152 & 26 & 49 & +2 & +0.7 \\
\hline & Mean/d & 76 & $5 \mathrm{I}$ & 9 & 16 & - & - \\
\hline \multirow[t]{8}{*}{2} & JS & 229 & 166 & 52 & 55 & -44 & -15 \\
\hline & FK & 208 & $12 \mathrm{I}$ & 44 & 49 & -6 & $-2 \cdot 0$ \\
\hline & $\mathrm{CM}$ & 239 & 186 & 56 & 34 & -37 & -12 \\
\hline & EM & 266 & 188 & 20 & $7 \mathrm{I}$ & - II & -377 \\
\hline & GU & 216 & 171 & 20 & 57 & -32 & -10 \\
\hline & $F M$ & 210 & 167 & 20 & 52 & -29 & -9.7 \\
\hline & Mean & 228 & 166 & 35 & 53 & -26 & $-8 \cdot 7$ \\
\hline & Mean/d & 76 & 55 & 12 & 17 & - & - \\
\hline \multirow[t]{8}{*}{3} & JS & rgr & 120 & 24 & 68 & $-2 \mathbf{I}$ & $-7 \cdot 0$ \\
\hline & $\mathrm{FK}$ & 163 & I 20 & 26 & 49 & -32 & - II \\
\hline & $\mathrm{CM}$ & I9I & 115 & 35 & 52 & - II & $-3 \cdot 7$ \\
\hline & $\mathrm{EM}$ & 224 & $\mathrm{I}_{5} \mathrm{I}$ & 22 & 48 & +3 & $+1 \cdot 0$ \\
\hline & GU & 186 & 107 & 19 & 64 & -4 & $-x \cdot 3$ \\
\hline & $\mathrm{FM}$ & 193 & I39 & 23 & 50 & -19 & $-6 \cdot 3$ \\
\hline & Mean & I9I & 125 & 25 & 55 & -14 & -4.7 \\
\hline & Mean/d & 63 & 42 & 8 & 19 & - & 一 \\
\hline
\end{tabular}

jects were near to $\mathrm{Na}$ balance accounts for the absence of any reduction in salt loss in the sweat during the acclimatization periods of studies 2 and 3 .

The subjects maintained a balance between $\mathrm{K}$ intake and output in study $\mathrm{I}$; there was a tendency for a small negative balance in studies 2 and 3 . The fall in $\mathrm{K}$ intake in the third study was associated with the greatly decreased $\mathrm{N}$ intake, but a fall in the urine loss largely compensated for this reduction in $\mathrm{K}$ intake. There was also a marked fall in the $\mathrm{K}$ concentration of the sweat in study 3 (see Table 7 ) but, because of the increased sweat output (Table 3), the total output was little different from that in study $\mathrm{I}$. There is an indication, therefore, that the level of dietary $\mathrm{K}$ intake can affect both the concentration in sweat and the output in urine. In this investigation the $\mathrm{K}$ loss in sweat represented $15 \%$ of total intake in studies 2 and 3 and $10 \%$ in study I, accounting, therefore, for a greater proportionate loss by sweat than was found with $\mathrm{Na}$.

\section{Fe balance}

The subjects' intake and output of Fe are shown in Table 6 and the concentration of $\mathrm{Fe}$ in the sweat in Table 7 . In studies $\mathrm{I}$ and 2 they were in positive balance, of the order of $10 \%$ of intake, and they were in negative balance in study 3 . This negative balance was the result of a reduced intake of $\mathrm{Fe}$, with no change in faecal or sweat 
Table 6. Iron intake, output and balance of six Tanzanian male adults for each study period

Total for $3 \mathrm{~d}(\mathrm{mg})$

\begin{tabular}{|c|c|c|c|c|c|c|c|}
\hline \multirow{2}{*}{$\begin{array}{l}\text { Study } \\
\text { period }\end{array}$} & \multirow[b]{2}{*}{ Subject } & \multirow[b]{2}{*}{ Intake } & \multicolumn{3}{|c|}{ Output } & \multirow[b]{2}{*}{ Balance } & \multirow{2}{*}{$\begin{array}{l}\text { Balance } \\
\text { (mg/d) }\end{array}$} \\
\hline & & & Urine & Sweat & Faeces & & \\
\hline \multirow[t]{8}{*}{ I } & JS & $99 \cdot 6$ & 0.25 & I.99 & $69 \cdot I$ & $+28 \cdot 4$ & +9.8 \\
\hline & FK & 123.9 & 0.48 & $1 \cdot 37$ & $74 \cdot 2$ & $+47 \cdot 8$ & +15.9 \\
\hline & $\mathrm{CM}$ & $127 \cdot 6$ & 1.02 & I.09 & $68 \cdot 4$ & $+57 \cdot 1$ & +19.0 \\
\hline & EM & 98.9 & 0.49 & 0.74 & $74 \cdot 6$ & $+22: I$ & +7.6 \\
\hline & $\mathrm{GU}$ & $93 \cdot 3$ & $I \cdot I I$ & 0.80 & $65 \cdot 4$ & +240 & \\
\hline & FM & 83.8 & 0.60 & 0.76 & $44 \cdot I$ & $+38 \cdot 4$ & $+\mathrm{x} 2 \cdot 8$ \\
\hline & Mean & $104 \cdot 5$ & 0.66 & $I \cdot I 3$ & 66.0 & $+36 \cdot 3$ & $+I 2 \cdot I$ \\
\hline & Mean/d & $34 \cdot 8$ & 0.22 & 0.38 & 22.0 & - & - \\
\hline \multirow[t]{8}{*}{2} & $\mathrm{JS}$ & $I 22 \cdot I$ & 0.13 & $I \cdot 30$ & 88.7 & $+32 \cdot 0$ & +10.7 \\
\hline & FK & 11112 & $I \cdot 71$ & $I \cdot 20$ & 63.7 & +44.6 & $+I_{4} \cdot 9$ \\
\hline & $\mathrm{CM}$ & 132.8 & 0.49 & $I \cdot 13$ & 63.6 & +67.6 & +22.5 \\
\hline & $\mathrm{EM}$ & $109 \cdot 8$ & 0.60 & 0.68 & 90.5 & +18.0 & +6.0 \\
\hline & $\mathrm{GU}$ & 103.9 & 0.57 & 0.80 & $78 \cdot 4$ & +24.1 & +8 \\
\hline & FM & $82 \cdot I$ & 0.68 & 0.64 & $82 \cdot 5$ & $-\mathrm{I} \cdot 2$ & -0.4 \\
\hline & Mean & 110.3 & 0.70 & 0.96 & $77 \cdot 9$ & +30.8 & +10.3 \\
\hline & Mean/d & $36 \cdot 8$ & 0.23 & 0.32 & $26 \cdot 0$ & - & - \\
\hline \multirow[t]{8}{*}{3} & JS & $47 \cdot 2$ & 0.69 & 0.83 & $98 \cdot 0$ & $-52 \cdot 3$ & $-17 \cdot 4$ \\
\hline & FK & $44 \cdot 5$ & 0.62 & 0.90 & 88.9 & $-45 \cdot 9$ & -15.3 \\
\hline & $\mathrm{CM}$ & $46 \cdot 0$ & 0.58 & 1.56 & $49^{\circ} 9$ & -6.0 & $-2 \cdot 0$ \\
\hline & $\mathrm{EM}$ & $70 \cdot 7$ & 0.34 & $I \cdot I I$ & $68 \cdot 7$ & $-2 \cdot 7$ & -0.9 \\
\hline & $\mathrm{GU}$ & $6 I \cdot r$ & 0.65 & 0.74 & 80.7 & $-21 \cdot 0$ & -7.0 \\
\hline & FM & $45 \cdot 6$ & 0.52 & 0.96 & $67 \cdot 0$ & -22.9 & $-7 \cdot 6$ \\
\hline & Mean & $52 \cdot 5$ & 0.57 & 1.02 & $75 \cdot 5$ & $-25 \cdot I$ & $-8 \cdot 4$ \\
\hline & Mean/d & 17.5 & O.19 & 0.34 & $75 \cdot 2$ & - & - \\
\hline
\end{tabular}

excretion. There was a lower sweat Fe concentration in studies 2 and 3, which was associated with the increase in sweat output, since total Fe excretion remained constant. Sweat Fe output never exceeded $2 \%$ of intake, but if the amount of dietary $\mathrm{Fe}$ absorbed is taken as the difference between intake and faecal excretion, then sweat excretion accounted for approximately $3 \%$ of dietary $\mathrm{Fe}$ absorbed in studies $\mathrm{I}$ and 2 , and always exceeded urinary Fe output.

\section{DISCUSSION}

Rothstein, Adolph \& Wills (I947) have shown that at high rates of sweating (400$1000 \mathrm{ml} / \mathrm{h}$ ), despite unrestricted access to drinking-water, a voluntary deficit of $3 \%$ of body-weight is often reached at the end of 5 or $6 \mathrm{~h}$; they state (p. 260) that 'water deficits accumulate between meals and are made good whenever a meal is eaten'. They cite two instances where deficits of 2200 and $1300 \mathrm{ml}$ were reduced to balances of $-\mathrm{I} 40$ and $+90 \mathrm{ml}$ respectively after a meal and fluid had been taken.

As a group, the subjects at Dar es Salaam, living their ordinary lives with moderate activity in hot, humid conditions, appeared to be in fairly close water balance when observed over $3 \mathrm{~d}$ periods. The total water imbalance/d was only $53 \mathrm{ml}$ and the most extreme overnight deficit observed was $1 \cdot 3 \%$ of total body-weight. The individual 
Table 7. Concentrations of sodium, potassium and iron in $24 h$ collections of whole-body sweat from six Tanzanian male adults for each study period

\begin{tabular}{|c|c|c|c|c|}
\hline Study & Subject & $\mathrm{Na}$ (mequiv./1) & $\mathrm{K}$ (mequiv./1) & $\mathrm{Fe}(\mathrm{mg} / \mathrm{l})$ \\
\hline \multirow[t]{7}{*}{ I } & JS & 4.99 & $4 \cdot 85$ & 0.283 \\
\hline & FK & 4.86 & $7 \cdot 17$ & $0.35^{\circ}$ \\
\hline & $\mathrm{CM}$ & 3.90 & $5 \cdot \mathrm{II}$ & 0.146 \\
\hline & $\mathrm{EM}$ & $6 \cdot 46$ & $3 \cdot 72$ & 0.145 \\
\hline & GU & 6.70 & $3 \cdot 25$ & 0.153 \\
\hline & FM & $2 \cdot 62$ & 3.02 & 0.127 \\
\hline & Mean & 4.92 & $4 \cdot 52$ & 0.201 \\
\hline \multirow[t]{7}{*}{2} & JS & 7.68 & $5 \cdot 62$ & $0.14 \mathrm{I}$ \\
\hline & FK & 5.25 & $5 \cdot 13$ & 0.140 \\
\hline & CM & 5.59 & 5.05 & 0.102 \\
\hline & EM & II 75 & $3 \cdot c 5$ & 0.104 \\
\hline & GU & 15.70 & $4 \cdot 24$ & 0.170 \\
\hline & FM & $8 \cdot 6 \mathrm{I}$ & 3.25 & 0.104 \\
\hline & Mean & $9 \cdot 10$ & 439 & 0.127 \\
\hline \multirow[t]{7}{*}{3} & JS & $7 \cdot 91$ & $3 \cdot 39$ & 0.117 \\
\hline & FK & $7 \cdot 59$ & 4.59 & 0.159 \\
\hline & $\mathrm{CM}$ & 10.97 & $4 \cdot 68$ & 0.209 \\
\hline & EM & $I I \cdot 33$ & $2 \cdot 80$ & $0.14 \mathrm{I}$ \\
\hline & GU & 12.54 & $3 \cdot 18$ & 0.124 \\
\hline & FM & $9 \cdot 44$ & 3.06 & 0.128 \\
\hline & Mean & 9.96 & $3 \cdot 62$ & 0.146 \\
\hline
\end{tabular}

daily values do, however, show a wider range than would be suggested by those given by Rothstein et al. (1947). Though twenty of the fifty-four observations were within the range of -140 and $+90 \mathrm{ml}$ cited by Rothstein and co-workers, the remainder were outside these values, the standard deviation being 280. Edholm (1972) found that soldiers in Aden, whose sweat rates were very high, also show average daily water balances which fluctuate greatly from day to day.

Interpretation of the results for $\mathrm{Na}$ excretion is made difficult by the very high urinary $\mathrm{Na}$ output of subject FK in study $\mathrm{I}$, which was considerably higher than his own or the other subjects' outputs in any other period. There is some reason to suspect that his intake was underestimated, and his urine Na values were equally high on each successive day of the balance. Apart from this one very divergent result, our subjects were generally in slightly negative $\mathrm{Na}$ balance. We do not regard them as having been $\mathrm{Na}$-depleted, and some of them were able to achieve almost complete balance. However, it is of interest that they were eating a salt-free diet and adding measured quantities of salt 'at table'. It is possible that some of them slightly underestimated their salt needs, being unaccustomed to eating salt-free food, and hence tended to go into negative balance. It appears that, in this study, $3-5 \mathrm{~d}$ was not a long enough period for all the subjects to adjust to eating salt-free food.

Although the $\mathrm{K}$ intakes fell in study 3 , there was no significant change in $\mathrm{K}$ balance and our subjects appeared to be in equilibrium.

The uniformly positive Fe balances in studies $\mathrm{I}$ and. 2, and negative balances in study 3 , show that our subjects were somewhat slow in adapting to changes in their dietary $\mathrm{Fe}$ intake. The diet in studies $\mathrm{I}$ and 2 contained more meat than the average 
hostel diet, and $\mathrm{Fe}$ is particularly well absorbed from meat (Conrad, I970). Between studies $I$ and 2 the faecal excretion of Fe had risen from an average of $22 \mathrm{mg} / \mathrm{d}$ to $26 \mathrm{mg} / \mathrm{d}$, showing that adaptation was taking place; and when the intake was approximately halved, in study 3 , the faecal excretion remained high, although the run-up period had been $5 \mathrm{~d}$ long, and the study itself continued for $3 \mathrm{~d}$. Thus, although the body's Fe absorption mechanisms can react to blood loss within $3^{-5} \mathrm{~d}$ (Conrad, 1970), changes in the diet did not produce such rapid adaptation.

The mean sweat losses of Fe were constant throughout the study and were unaffected either by increased sweating or by the diet. Green, Charlton, Seftel, Bothwell, Mayet, Adams, Finch \& Layrisse ( 1968 ) found that whole-body Fe turnover amounted to $\mathrm{I}-2.5 \mathrm{mg} / \mathrm{d}$; they observed no effect associated with heavy sweating but found an increased turnover when the diet was rich in Fe. Our range of output (sweat + urine) was $0.5-0.6 \mathrm{mg} / \mathrm{d}$, and we did not observe a dietary effect; but the studies are not exactly comparable since Green et al. consider total cutaneous loss, whereas our analyses were of cell-free sweat.

FAO (I970) recommends that diets should be sufficient to provide I $\mathrm{mg}$ absorbable $\mathrm{Fe} / \mathrm{d}$, taking into account an average daily urinary, faecal and cutaneous loss of $\mathrm{I}_{4} \mu \mathrm{g} / \mathrm{kg}$. Thus, in our subjects, sweating could have accounted for one-third of absorbed Fe and, since sweat Fe losses did not appear to decrease when the subjects went into negative balance, it seems possible that this could be an important component of $\mathrm{Fe}$ loss in circumstances in which only a small quantity of $\mathrm{Fe}$ is absorbed. This would not necessarily occur in all anaemic people, since Fe absorption is increased in such subjects; but when diets are rich in Fe-binding substances such as phytic acid or egg proteins, or deficient in ascorbic acid which promotes Fe absorption, skin losses might become significant. A varied diet, containing legumes and animal proteins other than egg, is of particular importance in maintaining $\mathrm{Fe}$ absorption.

The work reported in this paper and by Weiner et al. (1972) was carried out as part of a combined Tanzania-UK project within the Human Adaptability Section of the International Biological Programme of ICSU. We are indebted to Mrs C. Doré for statistical help.

\section{REFERENCES}

Bothwell, T. H. (1970). In Iron Deficiency p. I5I [L. Hallberg, H. G. Harwerth and A. Vannotti, editors]. New York: Academic Press.

Bothwell, T. H. \& Mallett, B. (1955). Biochem. F. 59, 599.

Collins, K. J., Eddy, T. P., Hibbs, A., Stock, A. L. \& Wheeler, E. F. (I971). Br. F. ind. Med. $26,246$.

Conrad, M. E. (1970). In Iron Deficiency p. 87 [L. Hallberg, H. G. Harwerth and A. Vannotti, editors]. New York: Academic Press.

Edholm, O. G. (1 972). In Advances in Climatic Physiology Ch. 10 [S. Ito, K. Ogata and H. Yoshimura, editors]. Tokyo: Igaku Shoin Ltd.

FAO (1970). Tech. Rep. Ser. Wld Hlth Org. no. 452.

Fox, R. (1967). Rep. U.S. publ. Hlth Serv. TR -44 , p. 267 .

Green, R., Charlton, R., Seftel, H., Bothwell, T., Mayet, F., Adams, B., Finch, C. \& Layrisse, M. ( с 968). Am. F. Med. 45, $33^{6}$.

Hegarty, P. V. J. (I966). Investigation of anaemogenic diets. PhD Thesis, University of London.

McCance, R. A., El-Neil, H., El-Din, N., Widdowson, E. M., Southgate, D. A. T., Passmore, R., Shirling, D. \& Wilkinson, R. T. (1971). Phil. Trans. R. Soc. B 259, 533. 
McCance, R. A. \& Widdowson, E. M. (I960). Spec. Rep. Ser. med. Res. Coun. no. 297.

Man, Y. K. \& Wadsworth, G. R. (I969). Clin. Sci. 36, 479.

Rothstein, A., Adolph, E. F. \& Wills, J. H. (I947). In Physiology of Man in the Desert Ch. 16. New York: Interscience Press.

Waterlow, J. C., Cravioto, J. \& Stephen, J. M. L. (1960). Adv. Protein Chem. I5, I3I.

Weiner, J. S. \& van Heyningen (1952). Br. F. ind. Med. 9, 56.

Weiner, J. S., Willson, J. O. C., El-Neil, H. \& Wheeler, E. F. (I972). Br. F. Nutr. 27, 543.

Wilson, G. M., Olney, J. M., Brooks, L., Myrden, J. A., Ball, M. R. \& Moore, F. D. (1954). Metabolism 3, 324.

Wootton, I. D. P. (1958). Biochem. F. 68, 197. 